\title{
MODEL KEGIATAN OUTDOOR GAMES ACTIVITIES UNTUK MAHASISWA PROGRAM STUDI OLAHRAGA REKREASI FAKULTAS ILMU KEOLAHRAGAAN UNIVERSITAS NEGERI JAKARTA
}

\author{
Hernawan $^{1}$
}

\begin{abstract}
Abstrak.Penelitian ini bertujuan untuk membuat Model Kegiatan Outdoor Games Activities Untuk Mahasiswa Program Studi Olahraga Rekreasi Fakultas Ilmu Keolahragaan Universitas Negeri Jakarta yang lengkap dengan spesifikasinya diharapkan dapat digunakan sebagai referensi dalam proses perkuliahan Mahasiswa Program Studi Olahraga Rekreasi. Penelitian dan pengembangan ini menggunakan metode Penelitian Pengembangan Research \& Development (R \& D) dari Borg and Gall. Subyek dalam penelitian dan pengembangan ini adalah mahasiswa Program Studi Ilmu Keolahragaan Konsentrasi Olahraga Rekreasi Fakultas Ilmu Keolahragaan Universitas Negeri Jakarta. Instrumen yang digunakan dalam penelitian dan pengembangan ini adalah angket yang digunakan untuk mengumpulkan data, adapun tahapan dalam penelitian dan pengembangan ini adalah, pada tahap: (1) analisis kebutuhan, (2) evaluasi ahli (evaluasi produk awal); (3) ujioba terbatas (ujicoba kelompok kecil); dan (4) ujicoba utama (field testing). Berdasarkan hasil pengembangan dapat disimpulkan bahwa: Model Kegiatan Outdoor Games Activities layak digunakan untuk proses perkuliahan Mahasiswa Program Studi Olahraga Rekreasi Fakultas Ilmu Keolahragaan Universitas Negeri Jakarta
\end{abstract}

Kata kunci: Pengembangan, Model, Outdoor Games Activities

\footnotetext{
${ }^{1}$ Hernawan adalah Dosen Fakultas Ilmu Olahraga, Universitas Negeri Jakarta
} 


\section{PENDAHULUAN}

Dalam UU No. 3 Tahun 2005 tentang

Sistem Keolahragaan Nasional, dinyatakan secara tegas bahwa olahraga rekreasi merupakan salah satu kegiatan dalam ruang lingkup olahraga selain olahraga pendidikan dan olahraga prestasi (Pasal 17). Berdasarkan definisi, tujuan, pembinaan dan pengembangan olahraga rekreasi, terlihat jelas bahwa olahraga rekreasi merupakan rangkaian yang tidak dapat dipisahkan dari kebutuhan hidup manusia. Secara lebih jauh, pembinaan dan pengembangan olahraga rekreasi diatur dalam Pasal 26.

Selain itu, pentingnya peran olahraga rekreasi ini dapat dilihat ketika olahraga rekreasi juga dijadikan sarana untuk pengembangan olahraga pendidikan. Hal ini ditegaskan dalam Pasal 25 ayat 8 yang menyatakan: "Pembinaan dan pengembangan olahraga pendidikan dapat memanfaatkan olahraga rekreasi yang bersifat tradisional sebagai bagian dari aktifitas pembelajaran". Dalam UU tersebut, juga ditegaskan bahwa olahraga rekreasi dapat dilaksanakan oleh setiap orang, satuan pendidikan, lembaga, perkumpulan, atau organisasi olahraga (Pasal 19 ayat 2). Hal ini memberi dukungan sekaligus peluang yang besar untuk mengembangkan olahraga rekreasi.

Dalam mewujudkan tantangan, serta peluang tersebut di atas, di Fakultas IImu Keolahragaan Universitas Negeri Jakarta selain membuka program studi olahraga rekreasi juga diajarkan mata kuliah teori dan praktek olahraga rekreasi, yang bertujuan membekali mahasiswa dengan pengetahuan teori maupun praktek di lapangan hal-hal yang berhubungan dengan kegiatan rekreasi.

Pada saat ini, pelaksanaan pembelajaran atau perkuliahan olahraga rekreasi di Fakultas Ilmu Keolahragaan Universitas Negeri Jakarta dirasakan kurang maksimal, ini dapat dilihat dari interaksi dan proses perkuliahan yang monoton dan berpusat pada dosen sebagai satusatunya sumber informasi, mahasiswa cenderung pasif dan hanya menerima pengetahuan dari dosen yang bersangkutan. 
Situasi ini mendorong peneliti untuk mengembangkan model pembelajaran olahraga rekreasi yang mampu mengakomodasi tujuan perkuliahan serta menciptakan situasi dan kondisi pembelajaran berjalan menjadi menyenangkan, tidak terpusat pada dosen, mendorong mahasiswa berinteraksi satu sama lainnya.

\section{Konsep Model yang Dikembangkan}

"Model adalah perbuatan yang kompleks. Perbuatan yang kompleks dapat diterjemahkan sebagai penggunaan secara integratif sejumlah komponen yang terkandung dalam perbuatan pengajar itu untuk menyampaikan pesan pengajaran". Oleh karena itu dalam dunia pengajaran ada baiknya guru menggunakan suatu prototipe dari suatu teori atau model. Disebut model karena hanya merupakan garis besar atau pokok-pokok yang memerlukan pengembangan yang sangat situasional.

Menurut Meyer dalam Tite "model dapat dimaknai sebagai objek atau konsep yang digunakan untuk mempresentasikan sesuatu hal yang nyata dan dikonversi untuk sebuah bentuk yang lebih komprehensif".

Model pembelajaran yang dilakukan merupakan peengembangan dari strategi pembelajaran yang sudah ada. Model disusun oleh guru sesuai dengan permasalahan pembelajaran. Model pembelajaran dilakukan untuk mengoptimalkan pembelajaran sesuai dengan standar kurikulum. Oleh karena itu model pembelajaran dapat bermanfaat untuk menciptakan lingkungan belajar yang kondusif dan efektif agar tujuan pembelajaran tercapai.

Berkembangnya ilmu pengetahuan dan teknologi pada dasarnya ikut memacu perkembangan ekonomi yang semakin cepat. Pesatnya kemajuan ekonomi di suatu negara juga tak bisa dilepaskan dengan dukungan aktifitas pekerjaan masyarakatnya. Ini berarti setiap orang dituntut untuk mampu bekerja semakin maksimal guna memenuhi perkembangan tersebut.

$\begin{array}{llr}\text { Kondisi ini tentu saja } \\ \text { menciptakan } & \text { tuntutan yang } \\ \text { berhubungan erat satu sama lainnya, } \\ \text { yakni tuntutan pekerjaan yang semakin }\end{array}$


tinggi dan tuntutan atas terpenuhinya harapan tingkat ekonomi yang baik pula. Umumnya, jika seseorang ingin mewujudkan kondisi tingkat ekonomi tertentu, maka semakin tinggi pula tuntutan pekerjaan pada dirinya. Akibatnya, banyak orang menghabiskan waktu bekerja dalam hidupnya guna memenuhi tuntutan tersebut. Keberhasilan meraih finansial yang baik tidak berarti dapat terbebas dari perubahan perilaku dan gaya hidup, seperti mulai jarangnya berolahraga, berperilaku konsumtif, pola makan yang buruk, dan kurangnya waktu istirahat. Realitas ini dapat ditemui pada mereka yang beraktifitas di sejumlah kota besar di Indonesia seperti Jakarta, Bandung, Semarang, Surabaya, Makasar, dan Medan.

Perubahan perilaku dan gaya hidup tersebut dalam kondisi tertentu umumnya berakibat pada kelelahan yang tidak sekedar fisik, namun juga kelelahan psikis yang seringkali membutuhkan solusi yang bersifat segera guna mempertahankan produktivitas kerja yang ada. Pada saat seperti itulah, orang biasanya membutuhkan rekreasi di waktu luang yang dimilikinya.

Istilah atau kata rekreasi hingga kini belum ada perumusan yang jelas dan tegas. Beberapa pihak mengemukakan bahwa rekreasi dirasakan sebagai suatu bentuk pengalaman, sebagai spirit hidup, sebagai pemulihan keteganganketegangan dalam bekerja dan ada juga yang memandang rekreasi sebagai lawan dari bekerja.

Rekreasi adalah suatu aktivitas atau kegiatan yang bersifat fisik, mental maupun emosional yang dilakukan pada waktu senggang dan didorong oleh keinginan atau suatu motif atau bentuk dan macam aktivitas, dilakukan secara bebas, tanpa paksaan, yang didasari oleh diri sendiri secara sukarela, yang bersifat universal, kegiatan rekreasi tersebut semata-mata ingin mendapatkan kepuasan atau kesenangan.

Dari uraian di atas bahwa rekreasi merupakan suatu aktivitas yang dilakukan pada waktu senggang yang dilakukan tanpa paksaan, kegiatan tersebut semata-mata ingin mendapatkan kepuasan dan 
kesenangan. Rekreasi merupakan suatu aktivitas untuk pengisian waktu senggang. Aktivitasnya antara lain seperti: olahraga, seni musik, seni drama, seni tari atau pergi ke suatu tempat dengan maksud untuk menghilangkan keteganganketegangan dan sebagai selingan pekerjaan sehari-hari, yang akhirnya akan mendatangkan kesenangan dan kepuasan bagi pelakunya

Mengenai rumusan atau arti dari pada rekreasi beberapa ahli memberikan rumusannya masingmasing. Namun demikian satu sama lain mengemukakan bahwa rekreasi merupakan pengisian waktu senggang dan bermaksud untuk mendapatkan kesenangan dan kepuasan bagi pelakunya. Rekreasi dapat di tafsirkan sebagai suatu bentuk pengalaman atau aktivitas pengisian waktu terluang, yang dipilih oleh individu karena ia ingin mendapatkan kesenangan dan kepuasan secara langsung. Higham dan Hinch berpendapat bahwa: Rekreasi adalah aktivitas suka rela yang berhubungan dengan pengisian waktu terluang, bermotif untuk mendapatkan kepuasan atau kesenangan.

Rekreasi merupakan hal yang penting dan menjadi kebutuhan setiap individu. Setiap orang ingin mendapatkan kesenangan, kepuasan, ingin menghilangkan keteganganketegangan baik ketegangan fisik maupun ketegangan mental atau sebagai selingan pekerjaan sehari-hari untuk memperoleh keseimbangan dan kesegaran fisik mental. Kesemuanya itu dapat diperoleh melalui kegiatan rekreasi yang sesuai dengan pilihannya masing-masing:

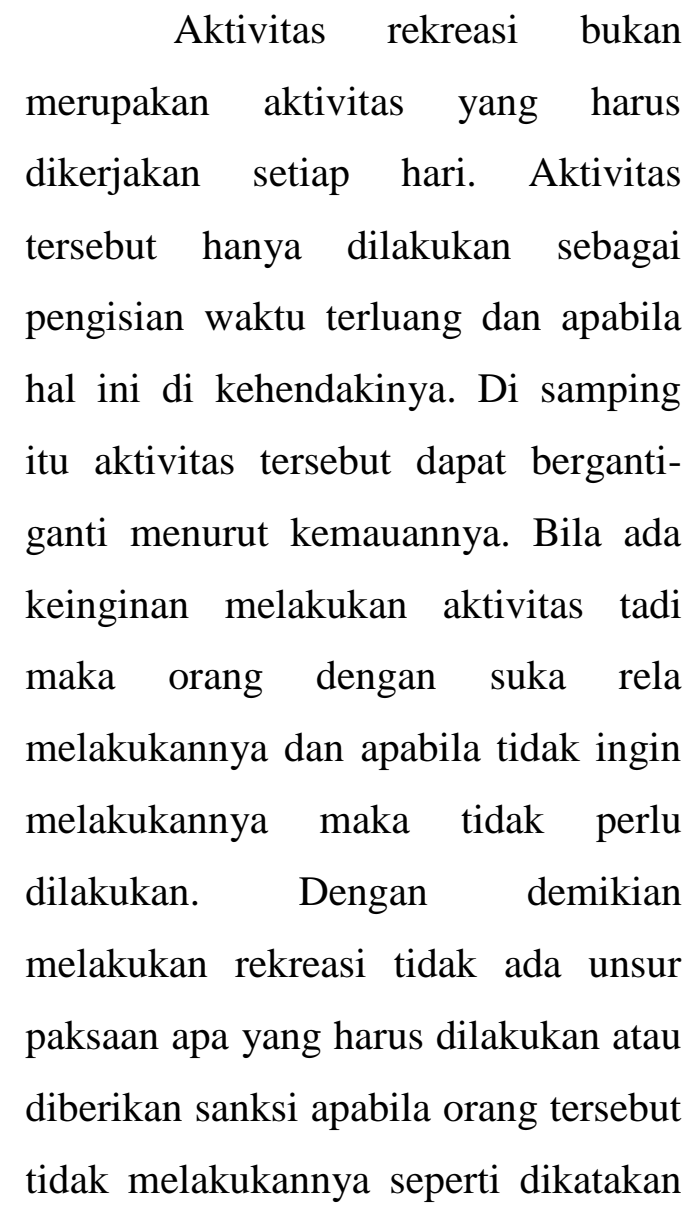

Aktivitas rekreasi bukan (n) 
oleh Hall dan Page sebagai berikut: Recreation is what you do when nobody and no social presure tell you what you must do. Rekreasi menghendaki aktivitas dan tidak selalu non aktif. Aktivitas rekreasi tidak mempunyai bentuk dan macam tertentu, artinya setiap orang dapat melakukan kegiatan rekreasi yang sesuai dengan kegemarannya.

Rekreasi dilakukan karena terdorong oleh keinginan atau mempunyai motif, motif tersebut sekaligus memilih gerakan atau bentuk dan macam aktivitas yang hendak dilakukan. Rekreasi hanya dilakukan pada waktu senggang (leisure time), hal ini berarti kegiatan yang tidak dilakukan dalam waktu senggang tidak digolongkan pada kegiatan rekreasi.

Rekreasi dilakukan secara bebas dari segala bentuk macam paksaan, bila seseorang tidak melakukan kegiatan rekreasi tidak akan di kenakan sanksi apapun. Rekreasi bersifat universal, artinya rekreasi tidak terbatas oleh umur, jenis kelamin, pangkat ataupun kedudukan sosial seseorang. Rekreasi dilakukan secara sungguh-sungguh dan mempunyai maksud-maksud tertentu.

Dalam rekreasi ada unsur flexibel, ini berarti bahwa rekreasi tidak dibatasi oleh tempat (indoor recreation dan outdoor recreation). Dimana saja rekreasi dapat dilakukan sesuai dengan bentuk dan macam kegiatan rekreasi yang dipilihnya. Rekreasi dapat dilakukan sendiri atau secara bersama-sama (kelompok). Kegiatan rekreasi tidak dibatasi oleh kemampuan seseorang, rekreasi tidak dibatasi oleh fasilitas atau alat-alat tertentu, rekreasi dapat di lakukan dengan alat-alat yang sederhana maupun dengan alat-alat modern.

Manusia hidup pada dasarnya memerlukan olahraga, agar tubuh tetap sehat dan tidak mudah terserang olah penyakit. Olahraga yang teratur mampu mengembangkan kondisi tubuh kembali dalam keadaan segar setelah melakukan aktifitas sehari-hari yang melelahkan. Olahraga merupakan suatu kegiatan manusia dan olahraga mempunyai pengaruh terhadap pribadi pelakunya, hal ini telah dikemukakan oleh Abdulkadir Ateng sebagai berikut: Olahraga adalah kegiatan 
jasmani atau kegiatan fisik manusia yang berpengaruh terhadap kepribadian dari pelakunya, sudah barang tentu kegiatan fisik dalam olahraga adalah kegiatan yang menuntut kesanggupan jasmaniah tertentu untuk menggunakan tubuh secara menyeluruh.

Kegiatan jasmani merupakan kegiatan utama dalam olahraga hingga apabila seseorang baru selesai berolahraga, wajar bila orang tersebut berkeringat. Olahraga dilakukan dalam bentuk-bentuk pertandingan, permainan, perlombaan ataupun campuran dari ketiga-tiganya.

Olahraga dapat mempengaruhi kehidupan seseorang, karena kehidupan seseorang sangat dipengaruhi oleh fisik, psikologis dan sosial, hal ini sesuai dengan dasardasar olahraga yang kemukakan oleh John Horne dkk, adalah:

1. Olahraga bersifat fisik: pertumbuhan fisik yang harmonis, yaitu pengaruh yang sangat baik terhadap pertumbuhan otot-otot, peredaran darah, pernafasan, pencernaan, reaksi dan sebagainya.
2. Olahraga bersifat rohani: seperti keberanian, ketekunan hati, percaya pada diri sendiri atau pada orang lain, jujur dan lainlain.

3. Olahraga bersifat sosiologis: memperbanyak pergaulan dan mengisi waktu luang.

Selain dapat mempengaruhi kehidupan seseorang olahraga juga mempunyai fungsi yang sangat penting yaitu sebagai reaksi, pelepasan dan pembebasan dari berbagai pikiran. Dalam kegiatan olahraga sebagai rekreasi, seseorang dapat bertemu dengan orang-orang lainnya untuk pergaulan yang menyegarkan dan menggembirakan. Kegiatan olahraga rekreasi juga tempat untuk melahirkan kegiatan yang memberi kesempatan untuk menyalurkan potensi yang ada pada dirinya dan juga sebagai tempat untuk menyatakan dirinya sehingga mendapat perlakuan atau penghargaan sebagai seorang pribadi. Toho Cholik Mutohir mendefinisikan olahraga sebagai berikut: Olahraga adalah proses sistematik yang berupa segala kegiatan atau usaha yang dapat mendorong, membangkitkan, mengembangkan, dan membina 
potensi-potensi jasmaniah dan rohaniah seseorang sebagai perorangan atau anggota masyarakat dalam bentuk permainan, perlombaan/pertandingan, dan kegiatan jasmani yang intensif untuk memperoleh rekreasi, kemenangan, dan potensi puncak dalam rangka pembentukan manusia Indonesia seutuhnya yang berkualitas berdasarkan Pancasila.

Olahraga merupakan kegiatan manusia yang wajar sesuai dengan kodrat illahi untuk mengembangkan dan membina potensi-potensi fisik, mental, dan rohaniah manusia demi kebahagiaan dan kesejahteraan pribadi dan masyarakat. Apabila olahraga dilakukan secara baik dan teratur akan dicapai tingkat kesehatan dan kesegaran jasmani yang tinggi. Juga ditanamkan sikap mental yang baik, seperti kejujuran semangat juang sportivitas dan kerjasama antar sesama.

Menurut Leonard yang dikutip Singgih yang secara khusus mengemukakan bahwa olahraga merupakan petualangan tubuh dan jiwa manusia (the adventures of body and mind) menuju suatu kesatuan harmonis. Dalam petualangan menuju harmonisasi tubuh dan jiwa ini seorang individu harus melalui serangkaian pengalaman baik yang bersifat cobasalah maupun secara lebih terarah untuk dapat menemukan potensipotensi yang tersembunyi dalam dirinya.

Sementara itu menurut Santoso dan kawan-kawan: Olahraga adalah serangkaian raga yang teratur dan terencana yang dilakukan orang untuk mencapai suatu maksud dan tujuan tertentu.

Sedangkan menurut Dewan yang dikutif Rusli dalam bukunya Olahraga sebagai aktifitas spontan, bebas, dan dilaksanakan selama waktu luang. Berdasarkan tujuan yang hendak dicapai, maka olahraga dibagi menjadi: Olahraga prestasi tekanannya pada bidang prestasi, Olahraga Rekreasi tekanannya pada rekreasi, Olahraga kesehatan tekanannya pada pencapaian kesehatan, dan Olahraga pendidikan tekanannya pada tujuan pendidikan.

Intensitas olahraga itu sendiri akan sangat tergantung pada tujuan yang hendak dicapai. Sedangkan 
manfaat bagi derajat kesehatan dinamis akan sangat tergantung pada intensitas pelaksanaannya Meskipun amat beragam bentuk dan jenis olahraga, tetapi masih dapat diidentifikasi persamaan umum yang menunjukan ciri khas olahraga yang dibentuk olah sebuah kriteria yaitu makna bermain dan permainan. Kriteria yang paling otentik adalah bahwa kegiatan olahraga tersebut didasarkan pada faktor kebebasan dan kesengajaan atas dasar kesadaran pelakunya untuk berbuat.

Komisi Disiplin Ilmu Keolahragaan menjelaskan tentang aktifitas-aktifitas olahraga dan tujuannya yang didefinisikan sebagai berikut:

1. Olahraga pendidikan adalah proses pembinaan menekankan penguasaan keterampilan dan ketangkasan berolahraga nilai nilai kependidikan melalui pembekalan pengalaman yang lengkap sehingga yang terjadi adalah proses sosialisasi melalui dan kedalam olahraga.

2. Olahraga kesehatan adalah jenis kegiatan olahraga yang lebih menitikberatkan kepada upaya mencapai tujuan kesehatan dan fitness yang tercakup kedalam konsep well being melalui kegiatan berolahraga.

3. Olahraga rekreatif adalah jenis kegiatan olahraga yang menekankan pencapaian tujuan yang bersifat rekreatif atau manfaat dari aspek jasmaniah dan sosial psikoligis.

4. Olahraga rehabilitatif adalah jenis kegiatan olahraga atau latihan jasmani yang menekankan tujuan bersifat terapi atau aspek psikis dan prilaku.

5. Olahraga kompetitif adalah jenis kegiatan olahraga yang menitik beratkan peragaan ferforma dan pencapaian prestasi maksimal yang lazim dikelola oleh organisasi olahraga.

Olahraga dilakukan karena berbagai alasan penting dari sisi pelakunya. Nilai-nilai dan manfaat (kemaslahatan) yang diperoleh para pelaku itu didapat dari partisipasi atau keterlibatan aktif sebagai pelaku dalam beberapa kegiatan yang bersifat hiburan, pendidikan, rekreasi, kesehatan, hiburan sosial, pengujian kemampuan diri atau kemampuan diri dibandingkan dengan orang lain. 
Dengan kata lain olahraga menjadi wahana untuk mengalami aspek pengalaman manusiawi.

Wilkerson dan Dodder yang dikutif Harsuki, dalam penelitianya menjelaskan fungsi dan tujuan olahraga adalah sebagai berikut:

1. Pelepasan emosi, olahraga adalah salah satu cara untuk menyatakan emosi dan mengendorkan ketegangan.

2. Menunjukkan identitas, olahraga memberikan kesempatan untuk dikenal dan untuk menunjukan kualitas diri.

3. Kontrol sosial, olahraga memberikan cara untuk mengontrol orang dalam suatu masyarakat bila ada penyimpangan prilaku.

4. Sosialisasi, olahraga berperan sebagai salah satu cara untuk terjadi kontak sosial sesama penggemar olahraga.

5. Agen perubahaan, olahraga menghasilkan perubahaan sosial, pula prilaku baru, dan menjadi satu faktor yang mengubah jalan sejarah. Umpamanya, olahraga memungkinkan untuk berinteraksi dari semua jenis manusia dan untuk mobilitas keatas berdasarkan kemampuan.

6. Semangat kolektif, olahraga menciptakan semangat kebersamaan yang membuat orang bersatu untuk mencapai tujuan bersama.

7. Sukses, olahraga memberikan perasaan berhasil, baik sebagai pemain maupun sebagai penonton, bila seorang pemain regu memperoleh sukses.

Olahraga dapat digunakan untuk memenuhi kebutuhan praktis dalam kehidupan karena memiliki daya tarik untuk mengembangkan berbagai kemampuan, menumbuhkan harapan harapan, memberikan pengalaman yang mengembangkan, meningkatkan kesegaran jasmani dengan mengikut sertakan sistem otototot dan belajar yang dihasilkan dari ikut sertanya dalam kegiatan olahraga.

Olahraga rekreasi sendiri dimulai dari Inggris ketika para Tuan Tanah banyak sekali yang memiliki waktu luang dan mengisi dengan aktifitas fisik di halaman Istana yang luas. Maka, terciptalah olahraga rekreasi yang dikenal di Eropa dengan aksi trim, di Amerika dikenal dengan recreational sport, dan biasanya dengan istilah umum disebut "Sport For All”. 
Dalam olahraga rekreasi, mengingat individu berpartisipasi peraturan permainan tidak berlaku secara langsung di dalamnya. Maka ketat sebagaimana olahraga prestasi. Hal ini sejalan dengan tujuannya yang bersifat rekreatif yaitu untuk memunculkan manfaat dari aspek jasmaniah, sosial dan psikologis. Dalam olahraga rekreasi, unsur bermain biasanya terkait sangat erat di dalamnya. Pentingnya bermain itu sendiri didukung oleh pendapat beberapa ahli pendidikan adalah Jhon Dewey, yang menyatakan bahwa bermain adalah sarana stimulasi untuk merangsang munculnya sikap individu yang sebenarnya disebabkan individu yang bersangkutan merasa enjoy dalam menjalankannya.

Jadi melalui bermain, perkembangan individu juga dapat dilihat, karena itu bermain merupakan sarana belajar secara alami. Bermain lebih dari sekedar aktifitas biologis, akan tetapi juga dapat digunakan untuk mencapai tujuan sosial dan budaya. Selain itu bermain tidak sekedar mempertahankan aktifitas, melainkan juga mengarahkan setiap orang untuk memperoleh insight dan pengalaman baru dari luar. Hal ini dimungkinkan tidak mengherankan jika rekreasi biasanya menjadi pilihan utama untuk memunculkan potensi kreatif seseorang.

Piaget dalam Mayesty mengatakan bahwa bermain adalah suatu kegiatan yang dilakukan berulang-ulang dan menimbulkan kesenangan/ kepuasan bagi diri seseorang, sedangkan Parten memandang kegiatan bermain sebagai sarana sosialisasi, diharapkan melalui bermain dapat memberi kesepakatan bereksplorasi, menemukan, mengekspresikan perasaan, bereaksi, dan belajar secara menyenangkan. Selain itu, kegiatan bermain dapat membantu anak mengenal tentang diri sendiri, dengan siapa ia hidup serta lingkungan tempat dimana ia hidup.

Selanjutnya Buhler dan Danziger dalam Roger dan Sawyers, berpendapat bahwa bermain adalah kegiatan yang menimbulkan kenikmatan; sedangkan Freud menyakini bahwa walaupun bermain tidak sama dengan bekerja tetapi 
menganggap bermain sebagai sesuatu yang serius.

Fleer berpendapat bahwa bermain merupakan kebutuhan, karena melalui bermain akan memperoleh pengetahuan yang dapat mengembangkan kemampuan dirinya. Bermain merupakan suatu aktifitas yang khas dan sangat berbeda dengan aktifitas lain seperti belajar dan bekerja yang selalu dilakukan dalam rangka mencapai suatu hasil akhir.

Vygotsky dalam Naughton percaya bahwa bermain membantu perkembangan kognitif anak secara langsung, tidak sekedar sebagai hasil dari perkembangan kognitif seperti yang dikemukakan oleh Piaget. Ia menegaskan bahwa bermain simbolik memainkan peran yang sangat penting dalam perkembangan berpikir abstrak.

Manfaat olahraga rekreasi sendiri telah dibuktikan diantaranya hasil penelitian Achmad Sanoesi yang menyimpulkan bahwa olahraga rekreasi berhasil meningkatkan semangat kerja guru. Dengan melakukan olahraga rekreasi di waktu luang, guru lebih bersemangat menjalankan tugasnya termasuk lebih rileks untuk mengatasi berbagai permasalahan mahasiswa yang dihadapinya sehari-hari.

Olahraga rekreasi merupakan aktivitas olahraga yang diselenggarakan untuk menggalakkan minat dan kegembiraan pelakunya. Olahraga rekreasi terbagi dalam lima kelompok yakni (1) olahraga instruksional, (2) informal, (3) intramural, (4) ekstramural, (5) olahraga di klub. Bentuk permainan disetiap bagian tidaklah sarna, bergantung pada kemampuan para pesertanya. Dengan demikian, penekanan dari rekreasi adalah dalam nuansa "mencipta kembali" (recreation) orang tersebut. upaya revitalisasi tubuh dan jiwa yang terwujud karena 'menjauh' dari aktivitas rutin dan kondisi yang menekan dalam kehidupan sehari-hari. Landasan kependidikan dari rekreasi karenanya kini diangkat kembali, sehingga sering diistilahkan dengan pendidikan rekreasi, yang tujuan utamanya adalah mendidik orang dalam bagaimana memanfaatkan waktu senggang mereka. 
Memelihara kesehatan tubuh merupakan dasar yang paling penting bagi kehidupan manusia "nilai olahraga untuk pemeliharaan kesehatan telah diketahui oleh umum maka pemerintah berbagai negara menilai olahraga sebagai bagian dari usaha pemeliharaan kesehatan." Olahraga rekreasi merupakan bagian dari pada olahraga secara keseluruhan dan merupakan salah satu cara yang lebih baik untuk aktivitas jasmani. Dengan aktivitas jasmani melalui olahraga rekreasi diharapkan akan terjadi perubahan-perubahan pada jaringan organ-organ tubuh.

$$
\text { Paru-paru; meningkatkan }
$$

efisiensi kerja paru-paru yang memungkinkan paru-paru orang terlatih bisa memproses udara lebih banyak dengan tenaga yang lebih sedikit. Selama melakukan kerja yang melelahkan seseorang yang terlatih bisa memproses udara hampir sebanyak dua kali lipat permenit, dari pada orang yang tidak terlatih. Maka orang yang terlatih bisa menyediakan oksigen lebih banyak bagi tubuhnya untuk dipergunakan dalam proses pembentukan energi.
Jantung; Meningkatkan efisiensi kerja jantung dalam berbagai segi. Jantung semakin kuat dan bisa memompakan darah lebih banyak dalam setiap denyutan. Jumlah denyutan yang dibutuhkan makin berkurang, seorang yang terlatih bisa mengurangi frekuensi denyut jantungnya sebanyak duapuluh kali permenit, dengan lain perkataan di banding dengan orang yang tidak terlatih. Denyut jantung orang yang terlatih lebih lambat dua puluh kali denyutan. Maka waktu istirahat dan tidur di waktu malam, denyut jantung orang yang terlatih bisa berkurang 10.000 kali denyutan. Bahkan dalam pengerahan tenaga maksimal jantung seorang yang terlatih mampu memompakan semua darah beserta oksigen yang di kandungnya yang di butuhkan oleh tubuh dalam frekuensi yang lebih lambat. Dari pada orang yang tidak terlatih. Sebaliknya jantung orang yang tidak terlatih memompakan darah dengan cepat sehingga membahayakan jantungnya selama pengerahan tenaga maksimal dalam usaha menyalurkan darah dan oksigen dalam jumlah yang cukup. 
Pembuluh darah; meningkatkan jumlah dan ukuran pembuluhpembuluh darah yang menyalurkan darah keseluruh tubuh mengsi penuh seluruh jaringan tubuh dengan oksigen untuk pembentukan energi. Meningkatkan volume darah, ini berarti pula lebih meningkatkan sarana penyaluran oksigen lebih banyak keseluruh jaringan tubuh yang memerlukan.

Otot; Meningkatkan ketegangan otot-otot dan pembuluhpembuluh darah mengubah jaringan otot yang lemah menjadi jaringan yang kokoh dan menjadi lebih kuat. Oksigen; meningkatkan konsumsi oksigen maksimal dalam tubuh, ini dicapai dengan cara meningkatkan efisiensi kerja semua sarana jaringan tubuh seperti: jantung, paru-paru, pembuluh-pembuluh darah, otot-otot serta jaringan jaringan tubuh lainnya.

Penyediaan dan penyaluran oksigen dalam proses penyediaan ini, makin meningkatkan pula kondisi tubuh secara menyeluruh, terutama bagian-bagian tubuh yang terpenting. Seperti telah disebutkan di atas, maka dengan demikian akan terbentuklah benteng pertahanan yang kuat dalam tubuh untuk mencegah terhadap berbagai macam gangguan penyakit.

Berdasarkan pendapat-pendapat tersebut ai atas, maka dapat ditarik kesimpulan, yang dimaksud olahraga rekreasi dalam penelitian ini adalah aktivitas olahraga yang diselenggarakan untuk menggalakkan minat dan kegembiraan pelakunya yang menekankan pencapaian tujuan yang bersifat rekreatif atau manfaat dari aspek jasmaniah dan sosial psikoligis.

\section{METODE PENELITIAN}

Perencanaan dan penyusunan dibuat agar dapat memberikat petunjuk dan tuntunan yang jelas dalam pelaksanaan penelitian nantinya dalam perkuliahan, perencanaan dan penyusunan model merupakan faktor yang menentukan keberhasilan sebuah program. Sehubungan dengan itu maka pengembangan model kegiatan Outdoor Games Activities yang akan disusun dan dikembangkan berupa modifikasi dan kreatifitas dalam bentuk kegiatan perkuliahan. 
Dalam dunia pendidikan hasil analisis tentunya diharapkan mampu memberikan jawaban mengenai apa kebutuhan mahasiswa saat ini. Pertimbangan model ini harus masuk ke ranah tujuan perkuliahan yang mengisyaratkan mahasiswa sebagai subyek belajar dan pembelajaran, pengorganisasian pembelajaran, penyampaian pembelajaran, pengelolaan pembelajaran dengan memperhatikan faktor tujuan pembelajaran, hambatan belajar, serta karakteristik mahasiswa, sehingga dapat diperoleh pembelajaran yang efektif, efesien dan memiliki kemenarikan dalam proses belajar mengajar.

\section{Langkah-Langkah Pengembangan Model}

Langkah selanjutnya adalah tahapan-tahapan yang dilakukan dalam pengembangan model. Langkah yang dilakukan dalam penelitian riset dan pengembangan model ini melalui tahapan-tahapan sebagai berikut:

a. Tahap evaluasi pertama yang dilakukan pada tahap rancangan bentuk model oleh pakar, evaluasi awal merupakan penilaian pertama dari para ahli untuk: menentukan apakah model sudah sesuai dengan karakteristik mahasiswa, (2) apakah model kegiatan Outdoor Games Activities yang dikembangkan cocok untuk mahasiswa sebelum di uji cobakan.

b. Tahapan evaluasi kedua yang dilakukan pada tahapan uji coba kelompok kecil. Pada evaluasi melalui hasil respon mahasiswa terhadap model model kegiatan Outdoor Games Activities dalam tahapan ujicoba ini dilakukan oleh mahasiswa atas tentang: (1) model model kegiatan Outdoor Games Activities mudah dipelajari, (2) model model kegiatan Outdoor Games Activities menarik dilakukan, (3) model model kegiatan Outdoor Games Activities sangat efektif dan lain-lainnya. Hasil respon mahasiswa atas model kegiatan Outdoor Games Activities yang telah dilaksanakan merupakan evaluasi penyempurnaan produk untuk mahasiswa program studi olahraga rekreasi sebelum model tersebut di uji lapangan pada 
kelompok yang heterogen dan lebih besar jumlah mahasiswanya.

c. Tahapan evaluasi akhir yang dilakukan pada tahapan uji lapangan kelompok besar dan heterogen tingkat keterampilannya. Hasil respon mahasiswa atas model sama seperti pertanyaan di tahapan evaluasi sebelumnya yang nantinya sebagai revisi penyempurnaan hasil produk model kegiatan Outdoor Games Activities dan di implementasikan.

\begin{tabular}{|c|c|}
\hline Penelitian & riset \\
\hline pengembangan & model \\
\hline menggunakan & langkah-langkah \\
\hline pengembangan & model \\
\hline dikembangkan oleh & Borg and $\mathrm{Ga}$ \\
\hline langkah-langkah & pengemban \\
\hline
\end{tabular}

1) Pertama kali yang ditentukan adalah Masalah atau potensi yang menjadi dasar pengembangan model

2) Selanjutnya dilakukan pengumpulan informasi sebagai landasan pemikiran untuk membuat konsep

3) Pembuatan model pembelajaran (rancangan produk), bentuk rancangan tersebut adalah model keseimbangan.
4) Validasi desain, dilakukan oleh ahli yang bersangkutan,

5) Revisi, dari hasil uji ahli (validasi desain)

6) Ujicoba produk, dilakukan dengan mempraktekkan model.

7) Revisi hasil uji coba produk

8) Ujicoba pemakaian atau uji kelompok yang lebih besar.

9) Revisi produk kedua, revisi dilakukan oleh ahli, guna memperoleh hasil yang sempurna.

10) Model dapat diproduksi

\section{Pengembangan Model}

Hasil dari model kegiatan Outdoor Games Activities Untuk mahasiswa Program Studi Olahraga Rekreasi Fakultas Ilmu Keolahragaan Universitas Negeri Jakarta ditulis dalam bentuk buku panduan. Buku tersebut menyajikan berbagai model olahraga rekreasi yang dikemas dalam beberapa model Permainan Luar Ruangan (Outdoor Games Activities) yang telah dikombinasikan dengan tingkat kesulitan yang berbeda.

Permainan Luar Ruangan (Outdoor Games Activities) akan dilaksanakan secara berulang-ulang secara berkelompok di setiap model.. 
Setiap model disajikan dalam bentuk yang sama tetapi langkah-langkah yang berbeda di setiap model permainan serta dapat diterapkan dalam proses aktifitas fisik agar nantinya diharapkan dapat mencapai tujuan aktifitas fisik yang sesuai.

\section{Hasil Analisis Kebutuhan}

Analisis kebutuhan pada penelitian model kegiatan Outdoor Games Activities Untuk mahasiswa Program Studi Olahraga Rekreasi Fakultas Ilmu Keolahragaan Universitas Negeri Jakarta bertujuan untuk menganalisis kebutuhan model Olahraga Rekreasi untuk dilakukan.

Adapun hasil analisis kebutuhan dalam penelitian ini menggunakan data wawancara dengan Dosen Matakuliah Rekeasi dan Olahraga Rekreasi pada tanggal 22 Maret 2016 yang akan disajikan secara naratif sebagai berikut: 1) sebagian besar materimkuliah hanya permainan yang monoton. 2) kurang melakukan aktifitas fisik yang harusnya di lakukan untuk pemenuhan kebugaran jasmani 3) Minimnya pengetahuan tentang olahraga rekreasi. (4) Mahasiswa menyatakan sangat setuju bila dikembangkan kegiatan Outdoor Games Activities.

\section{Pembuatan Produk Awal}

Setelah menyelesaikan tahap analisis kebutuhan dilanjutkan dengan pembuatan produk awal dengan kebutuhan mahasiswa program studi Olahraga Rekreasi. Hasil analisis kebutuhan mendorong peneliti membuat model kegiatan Outdoor Games Activities untuk mahasiswa Program studi Olahraga Rekreasi dengan 20 model.

\section{Evaluasi Para Ahli}

Sebelum model kegiatan Outdoor Games Activities untuk mahasiswa Program studi Olahraga Rekreasi yang telah dibuat dapat dinyatakan valid dan layak untuk diuji cobakan kepada subjek penelitian, maka peneliti terlebih dahulu melakukan validasi atau uji kelayakan model Olahraga Rekreasi kepada tiga orang ahli yaitu: 1 ahli permainan, 1 ahli rekreasi serta 1 ahli tes dan pengukuran olahraga. Ketiga ahli tersebut menilai rancangan model yang dibuat sehingga akan layak untuk diuji cobakan. 
Berdasarkan uji ahli yang dilakukan dapat ditarik kesimpulan bahwasanya model kegiatan Outdoor Games Activities untuk mahasiswa Program studi Olahraga Rekreasi layak dan dapat digunakan untuk aktifitas fisik perkuliahan mahasiswa.

Uji ahli yang dilakukan oleh peneliti terhadap tiga ahli terdapat beberapa saran yang membangun untuk penyempurnaan model kegiatan Outdoor Games Activities diantaranya:

1. Petunjuk pelaksanaan permainan harus dibuat secara jelas supaya mudah untuk dipahami.

2. Peraturan permainan harus dibuat secara jelas supaya mudah untuk dipahami.

\section{Revisi Produk}

Berdasarkan data yang dukumpulkan dari masing-masing ahli yang terdiri dari: 1 ahli permainan ,1 ahli rekreasi dan 1 ahli tes dan ahhli pembelajaran terdapat beberapa rancangan produk yang perlu di revisi sebelum menjadi model final dan di uji cobakan pada kelompok kecil. Revisi produk dimaksudkan agar rancangan produk yang dibuat lebih sempurna.

\section{PEMBAHASAAN}

\section{Penyempurnaan Produk}

Berdasarkan hasil ujicoba
kelompok besar model kegiatan
outdoor games activities untuk
mahasiswa program studi olahraga
rekreasi dapat dan layak untuk digunakan sebagai bahan ajar mata kuliah olahraga rekreasi. Halini dapat dilihat dari antuiasme mahasiswa dalam mengikuti kegiatan tersebut, selain itu ketertarikan mahasiswa akan materi yang disajikan sehingga semuamahasiswa mengikuti dan menikmati kegiatan ke 20 model kegiatan tersebut

Produk yang dikembangkan ini bertujuan untuk membentuk meningkatkan tercapainya tujuan pembelajaran olajraga rekreasi. Produk ini setelah dikaji mengenani beberapa kelemahan yang perlu pembenahan sesuai diatas maka dapat disampaikan beberapa keunggulan produk ini antara lain:

1. Mahasiswa lebih aktif dalam mengikuti proses perkuliahan. 
2. Mahasiswa terlihat gembira dan antusias.

3. Model kegiatan outdoor games activities ini dilakukan dari yang mudah ke yang sulit.

4. Tingkat kompetisi yang tinggi sehingga membuat mahasiswa lebih bersemangat.

5. Memerlukan sarana yang lebih banyak dari perkuliahan yang sebelumnya tetapi mampu diterapkan sesuai dengan karateristik mahasiswa program studi olahraga rekreasi

\section{Keterbatasan Penelitian}

Penelitian ini telah telah diupayakan secara maksimal sesuai dengan kemampuan dari peneliti, namun dalam penelitian ini masih terdapat beberapa keterbatasan yang harus diakui dan dikemukaakan sebagai bahan pertimbangan dalam menggeneralisir hasil dari penelitian yang dicapai.

Adapun keterbatasan-keterbatasan tersebut antara lain sebagai berikut:

1. Uji coba lapangan penelitian ini hanya dilakukan pada satu program studi yaitu mahasiswa program studi Olahraga Rekreasi dan tidak melibatkan program studi lainnya di Fakultas Ilmu Kelolahragaan Universitas Negeri Jakarta.

2. Adanya faktor-faktor psikologis yang diduga ikut mempengaruhi hasil penelitian yang tidak dapat dikontrol, antara lian : minat, percaya, dan faktor psikologis lainnya.

3. Adanya faktor lain yang diduga ikut mempengaruhi hasil penelitian yang tidak dapat terkontrol seperti dari faktor kondisi fisiknya, antara lain tinggi badan, kekuatan, koordinasi gerak serta kondisi fisik.

\section{KESIMPULAN}

Dalam penelitian pembuatan model kegiatan Outdoor Games Activities untuk Mahasiswa Program Studi Olahraga Rekreasi yang dikemas dalam buku. Berdasarkan data yang telah dikumpulkan dari hasil penelitian yang terdiri dari validasi ahli, dan uji coba kelompok kecil, maka peneliti dapat menarik kesimpulan bahwa:

1. Pembuatan model yang diperoleh secara keseluruhan dari ahli permainan menyatakan bahwa model yang dibuat termasuk 
dalam kategori baik dan layak digunakan.

2. Pembuatan model yang diperoleh secara keseluruhan dari ahli rekreasi menyatakan bahwa model yang dikembangkan termasuk dalam kategori baik dan layak digunakan.

3. Pembuatan model yang diperoleh secara keseluruhan dari ahli pembelajaran dan pengukuran olahraga menyatakan bahwa model yang dikembangkan termasuk dalam kategori baik dan layak digunakan..

4. Uji coba kelompok kecil dan kelompok besar dinyatakan layak untuk dipergunakan.

5. Melalui model olahraga rekreasi yang telah peneliti buat model kegiatan Outdoor Games Activities layak dipergunakan sebagai aktifitas fisik pada Mahasiswa Program Studi Olahraga Rekreasi.

Penerapan model kegiatan

Outdoor Games Activities yang telah dibuat oleh peneliti dinilai cocok digunakan dalam proses aktifitas fisik, khususnya pada permainan luar ruangan. sehingga dapat memberikan kontribusi yang baik dalam proses menjaga kebugaran jasmani Mahasiswa Program Studi Olahraga Rekreasi.

\section{SARAN}

Sehubungan dengan produk yang dibuat yaitu model kegiatan Outdoor Games Activities untuk Mahasiswa Program Studi Olahraga Rekreasi yang dikemas dalam bentuk permainan luar ruangan peneliti akan memberikan saran-saran yang meliputi saran pemanfaatan, saran diseminasi, dan saran pengembangan lanjutan.

1. Saran Pemanfaatan

Pada pemanfaatan produk ini harus memperlihatkan kondisi sarana dan prasarana yang ada. Produk ini diharapkan menjadi alternatif kegiatan aktifitas fisik yang menjadi rujukan Mahasiswa Program Studi Olahraga Rekreasi,

a. Mahasiswa Program Studi Olahraga Rekreasi

Produk model olahraga rekreasi yang dikemas dalam bentuk buku panduan permainan luar ruangan ini sebaiknya dilihat atau dipelajari terlebih dahulu sebelum 
melaksanakan kegiatan praktik permainan luar ruangan, sehingga diharapkan dapat menarik minat Mahasiswa Program Studi Olahraga Rekreasi dalam bergerak, karena Mahasiswa Program Studi Olahraga Rekreasi akan lebih mudah dalam memahami materi selain itu juga permainan akan lebih menyenangkan.

b. Program Studi Olahraga Rekreasi dan Fakultas Ilmu Keolahragaan Universitas Negeri Jakarta. Model olahraga rekreasi ini sebaiknya ditambahkan sebagai bahan kepustakaan. Sehingga bagi mahasiswa yang ingin melakukan penelitian dan pengembangan sejenis hendaknya penelitian ini dapat digunakan sebagai acuan dalam meneliti.

2. Saran Diseminasi

Dalam pembuatan produk ini peneliti menyarankan, Sebelum menyebarluaskan produk ini perlu tahapan evaluasi dari ahli yang berguna untuk menyempurnakan produk, serta harus memperhatikan sasaran yang akan diuji dan disesuaikan dengan kondisi sasaran yang ingin dituju baik isi maupun kemasan, karena model olahraga rekreasi ini dibuat berdasarkan atas kondisi lingkungan yang ada di Program Studi Olahraga Rekreasi. Sehingga model olahraga rekreasi ini dapat lebih menarik dan bermanfaat.

3. Saran Pengembangan Lebih Lanjut Dalam pengembangan penelitian ini ke arah lebih lanjut, peneliti mempunyai saran-saran sebagai berikut:

a. Dalam pengembangan produk berupa permainan luar ruangan diperlukan kreatifitas dan inovatif dalam memanfaatkan sarana dan prasarana yang berguna membantu Mahasiswa Program Studi Olahraga Rekreasi agar lebih cepat dalam mempelajari materi yang diberikan dan menambah kemenarikan dan antusias Mahasiswa Program Studi Olahraga Rekreasi dalam kegiatan aktifitas fisik.

b. Dalam penyebarluasan produk, peneliti memberi saran yaitu bahwa sebelum disebarluaskan sebaiknya produk ini dievaluasi kembali dan disesuaikan dengan 
kondisi sarana yang akan digunakan.

\section{DAFTAR PUSTAKA}

Abdulkadir Ateng. Azas-Azas Olahraga. Jakarta: Departemen Pendidikan dan Kebudayaan Direktorat Jendral Pendidikan tinggi Proyek Pembinaan Tenaga Pendidikan, 1998.

Achmad Sanoesi, Hubungan Antara Kegiatan Olahraga Rekreasi dengan Kinerja Guru. Jakarta: FPOK IKIP Jakarta, 1990.

Benny A. Pribadi. Model Desain Sistem Pembelajaran. Jakarta: Dian Rakyat, 2009.

C. Michael Hall and Stephen J. Page. The Geography of Tourism and

Direktorat Jenderal Olahraga dan Pemuda. Rekreasi Terarah Untuk Pemuda. Jakarta: Direktorat Jenderal Olahraga dan Pemuda, Departemen $\mathrm{P}$ dan K, 2008.

Edward Wieczoreck. Masalahmasalah Organisasi dan Management Keolahragaan. Olympic Solidarity IOC tahun 1975.

G. Mac Naughton. Shaping Early Childhood: Learners, Curriculum and Contexts, terjemahan Solehudin. Midenhead, Berkshire: Open University Press, 2003.
Recreation. New York: Routledge, 2006.

Charles K. Brightbill. Recreation, a Guide to Its Organization. London: Arizona: Me DrawHill International, 1994.

Cheryl Mallen and Lorne J. Adams. Sport, Recreation and Tourism Event Management, Theoretical and Practical Dimensions. Burlington: Elseiver, 2008.

Cony R.Semiawan. Catatan Kecil Tentang Penelitian dan Pengembangan Ilmu Pengetahuaan. Jakarta: Kencana, 2007.

Cosby S.Roger dan Janet K.Sawyers. Play in the lives of children. Washington DC: NAEYC, 1995.

Gayle Jennings. Water-Based Tourism, Sport, Leasuer, and Recreation Experiences. Burlington: Elseiver,2007.

Harsuki. Perkembangan Olahraga Terkini. Jakarta: PT Raja Grafindo Persada, 2003.

Hayden Ramsay. Reclaiming Leasure; art, Sport, and Phylosophy. New York: Macmillan, 2005.

James Higham and Tom Hinch. Sport and Tourism: Globalization, Mobility and Identity. Burlington: Elseiver, 2009. 
John Horne, Alan Tomlinson, Garry Whanel. Understanding Sport. London: E \& FN Spon, 2005.

Komisi Disiplin Ilmu Keolahragaan. Ilmu Keolahragaan dan Rencana pengembangannya. Jakarta: Depdiknas 2000.

Mary Mayesty. Creative Activities for Young Children $4^{\text {th }}$ Ed: Play, Development, and Creativity. New York: Delmar Publisher Inc, 1990.

Meredith D. Gall, Joyce P. Gall. Walter R. Borg, Eighth Edition Educational Research. NewYork, 2007.

Ratal Wirjasantosa. Supervisi Pendidikan Olahraga. Jakarta: PT Universitas Indonesia, 1984.

Rusli Lutan. Olahraga dan Etika Fair Play. Jakarta: Direktorat Pemberdayaan Ilmu Pengetahuan dan Teknologi Olahraga Direktorat Jendral Olahraga Departemen Pendidikan Nasional 2001.

Santoso, dkk. Manusia dan Olahraga. Bandung : ITB 2005.

Singgih D. Gunarsa. Psikologi Olahraga: Teori dan praktik. Jakarta: PT. Gunung Mulia, 1996.

Sue Docket dan Marlyn Fleer. Play and Pedagogy in Early Childhood-Bending the Rules. Sidney: Harcourt, 2000.
Sugiyono. Metode Penelitian Pendidikan Pendekatan Kuantitatif, Kualitatif dan $R \& d$. Bandung: Alfabeta, 2008.

Sugiyono. Metode Penelitian Kuantitatif, Kualitatif dan $R \&$ $D$. Bandung: Alfabeta, 2013.

Tite Juliantine dkk. Model-Model Pembelajaran Dalam Pendidikan Jasmani (Bandung: Bintang WarliArtika, 2013.

Toho Cholik. Gagasan-Gagasan Tentang Pendidikan Jasmani Dan Olahraga. Surabaya: Unesa University Press, 2002.

Yusuf Adisasmita. Rekreasi Pendidikan. Jakarta: FPOK IKIP Jakarta, 1989. 